\title{
PENERAPAN PERANGKAT PRAKTIK PENGECORAN ALUMINIUM PADA MATA PELAJARAN TEKNOLOGI MEKANIK UNTUK SISWA SMK
}

\author{
Tiyas Dwi Setiawan', Tiwan $^{2}$, Arianto Leman ${ }^{3}$ \\ 1,2,3 Pendidikan Teknik Mesin Fakultas Teknik Universitas Negeri Yogyakarta \\ tyaz.setiawan@yahoo.co.id
}

\begin{abstract}
This article presents the application of aluminum casting foundry practice equipment in SMK $N 1$ Magelang and the evaluation of the learning achievement. The research methods being used was quasi experiment with Pretest Posttest Control Group Design. The population of this research was all of the $126 \mathrm{X}$ grade students of Machining department. The sampling using the incidental sampling methods resulting in the choice of MC and MA class, each having 31 students as samples. MC class was selected as control group and MA was class selected as treatment group. Data collection was carried out using observation and test, and then analyzed using Sign Test. The experiment resulted in 30 students of the treatment group passed the minimum mastery criteria (score 75), while for the control group it is only 10 students. The learning achievements of the treatment group in average was 82.78 which is higher than the control group with an average of 72.43 . The increase in the average learning achievements for the treatment group is $37 \%$ while for the control group is 25 $\%$.
\end{abstract}

Keywords: aluminum casting practice, learning achievement, sign test

\begin{abstract}
ABSTRAK
Penelitian ini bertujuan untuk mengetahui perbedaan prestasi belajar siswa yang menggunakan perangkat praktik pengecoran aluminium pada mata pelajaran Teknologi Mekanik di SMK. Metode yang digunakan adalah kuasi eksperimen dengan Pretest Posttest Control Group Design. Populasi penelitian adalah seluruh siswa kelas X Teknik Pemesinan SMK Negeri 1 Magelang yang berjumlah 126 siswa. Kelas X MC dan X MA dengan masing-masing 31 siswa dipilih menjadi sampel dengan metode sampling insidental. Kelas X MC dipilih sebagai kelompok kontrol dan kelas X MA dipilih sebagai kelompok perlakuan. Data dikumpulkan dengan observasi dan tes, kemudian dianalisis menggunakan uji tanda. Setelah diberikan tindakan diketahui bahwa siswa yang mencapai KKM (75) pada kelompok perlakuan sebanyak 30 siswa, sedangkan pada kelompok kontrol hanya 10 siswa. Rata-rata prestasi belajar kelompok perlakuan adalah 82,78 sedangkan kelompok kontrol 72,43. Peningkatan rata-rata prestasi belajar kelompok perlakuan mencapai $37 \%$ sedangkan kelompok kontrol $25 \%$.
\end{abstract}

Kata kunci: perangkat praktik pengecoran aluminium, prestasi belajar siswa

\section{PENDAHULUAN}

Undang-undang Sistem Pendidikan Nasional Nomor 20 Tahun 2003 Bab I, menyatakan bahwa pendidikan adalah usaha sadar dan terencana untuk mewujudkan suasana belajar dan proses pembelajaran agar peserta didik secara aktif mengembangkan potensi dirinya untuk memiliki kekuatan spiritual keagamaan, pengendalian diri, kepribadian, kecerdasan, akhlak mulia, serta keterampilan yang diperlukan dirinya, masyarakat, bangsa dan negara. Oleh sebab itu, peran pendidikan menjadi sangat penting, karena pendidikan mampu memberikan perubahan tingkah laku manusia ke arah yang lebih baik. Saat ini pemerintah sedang menggiatkan peran pendidikan kejuruan dengan meningkatkan jumlah proporsi pendidikan kejuruan. Selain itu, arah kebijakan pemerintah juga berupa peningkatan layanan pendidikan yang dilaksanakan melalui penyediaan fasilitas pendidikan berupa pembangunan dan pengembangan lembagalembaga kejuruan, penambahan staf pengajar, 
dan penyediaan fasilitas pendukung pendidikan. Sekolah Menengah Kejuruan atau sering disebut SMK ini tidak semua memiliki sarana prasarana untuk mendukung proses belajar mengajar. Di mana SMK ini harus menciptakan generasi yang memiliki pengetahuan, kemampuan, ketrampilan, dan keahlian sesuai dengan bidang keahliannya untuk bersaing di dunia kerja setelah siswa lulus dari SMK.

Surat Keputusan Direktur Jenderal Pendidikan Menengah Kementerian Pendidikan Dan Kebudayaan nomor: 7013/D/KP/2013 tentang spektrum keahlian pendidikan menengah kejuruan menyatakan bahwa Teknik Pengecoran Logam merupakan salah satu paket keahlian yang harus dimiliki oleh lulusan SMK Program Keahlian Teknik Mesin. Faktanya di lapangan banyak SMK Program Keahlian Teknik Mesin tidak banyak yang membahas mengenai pengecoran. Ada pula SMK yang memberikan pengetahuan tentang pengecoran ini hanya melalui sub bab mata pelajaran. Dengan hanya ditaruh pada sub bab mata pelajaran maka pengetahuan tentang pengecoran ini hanya sebatas teori saja tanpa dibekali dengan praktik.

SMK Negeri 1 Magelang juga menyelenggarakan Jurusan Teknik Pemesinan. SMK N 1 Magelang ini memiliki sarana prasarana yang lengkap dan modern, seperti bengkel praktik kerja bangku dengan 36 ragum serta perlengkapannya, bengkel las dengan 2 buah mesin las MIG, 5 mesin las SMAW serta perlengkapannya, laboratorium $\mathrm{CNC}$ dengan 2 mesin bubut $\mathrm{CNC}, 2$ mesin frais $\mathrm{CNC}$, laboratorium gambar manual dengan 36 meja gambar dan perlengkapannya, laboratorium CADD dengan 36 komputer berbasis program Autocad dan Inventor, bengkel kerja mesin bubut dan frais dengan 6 mesin frais universal, 12 mesin bubut konvensional dan 4 mesin bubut retrofit, 1 mesin slotting beserta perlengkapannya, di bengkel kerja gerinda ada 2 mesin cutting tools, 1 mesin gerinda silindris, dan 1 mesin surface grinding. Selain itu kurikulum yang diterapkan di SMK N 1
Magelang ini sudah menggunakan kurikulum 2013 yang memiliki empat aspek penilaian yaitu aspek pengetahuan, aspek sikap, aspek ketrampilan dan aspek perilaku.

Dengan diterapkannya kurikulum 2013 ini banyak mata pelajaran yang ditambah dan ada pula yang dirampingkan, seperti mata pelajaran teknologi mekanik. Mata pelajaran teknologi mekanik ini sebelum diterapkan kurikulum 2013 merupakan mata pelajaran praktik penggunaan perkakas tangan. Kemudian setelah diterapkan kurikulum 2013 mata pelajaran teknologi mekanik merupakan gabungan antara mata pelajaran pengukuran, praktik penggunaan perkakas tangan, pengenalan dasar mesin, dan ilmu bahan. Dalam mata pelajaran teknologi mekanik ini ada materi (sub bab) tentang pengolahan bahan dan pengerjaan logam. Pada pelaksanaannya materi pengerjaan dan pengolahan logam hanya sebatas teori di dalam kelas tidak diimbangi dengan praktik khususnya praktik pengecoran aluminium. Hal ini dikarenakan belum adanya bengkel khusus pengecoran aluminium. Selain itu kondisi teknisi bengkel teknologi mekanik belum sepenuhnya siap dengan kegiatan praktik pengecoran aluminium yang terkendala dengan pengadaan perlengkapan dan bahan untuk praktik pengecoran aluminium. Sehingga terjadi ketidakseimbangan teori dengan praktik pengolahan dan pengerjaan logam khususnya pengecoran aluminium.

Fitrianto (2016) menjelaskan dalam penelitiannya dengan judul Implementasi Tungku Pelebur Logam untuk Meningkatkan Hasil Belajar Materi Pengecoran Logam Siswa Kelas X Jurusan Teknik Pemesinan di SMK Muhamadiyah Prambanan menunjukkan pengaruh positif dalam meningkatkan pengetahuan siswa tentang subjek pengecoran yang terdiri dari: keselamatan kerja, pengecoran alat, ketrampilan melakukan pengecoran logam, dan juga meningkatkan motivasi belajar. Selain itu Slameto (2013) mengatakan bahwa faktor yang mempengaruhi prestasi belajar ada dua yaitu faktor intern dan 
faktor ekstern, di mana faktor ekstern ini meliputi metode mengajar, kurikulum, relasi siswa dengan guru, disiplin sekolah, alat pelajaran, waktu sekolah, alat pelajaran, gedung sekolah dan standar pelajaran. Apabila penelitian dari Fitrianto dan pendapat dari Slameto ditarik kesimpulan maka dengan menggunakan saran prasarana yang memadai dapat meningkatkan prestasi belajar siswa.

Berdasarkan uraian di atas maka perlu ditelaah penerapan perangkat praktik pengecoran aluminium pada mata pelajaran teknologi mekanik di SMK N 1 Magelang. Penelitian ini bertujuan untuk mengetahui prestasi belajar siswa dalam mata pelajaran teknologi mekanik khususnya pengecoran aluminium, mengetahui perbedaan prestasi belajar siswa dan mengetahui persentase peningkatan prestasi belajar siswa terhadap pengaruh penerapan perangkat praktik pengecoran aluminium untuk mendukung kesiapan dalam menghadapi dunia kerja. Sehingga spektrum keahlian pendidikan menengah kejuruan yang tercantum dalam Surat Keputusan Direktur Jenderal Pendidikan Menengah Kementerian Pendidikan Dan Kebudayaan nomor: 7013/D/KP/2013 dapat terlaksana dengan baik.

\section{METODE}

Metode penerapan perangkat praktik pengecoran aluminium di SMK N 1 Magelang melalui tahap pembuatan dan pengadaan perangkat praktik, uji coba perangkat, membuat instrumen, validasi instrumen, pengumpulan data dengan cara observasi, tes dan dokumentasi, kemudian olah data dan penyajian data.

Penelitian ini menggunakan pendekatan penelitian kuasi eksperimen dengan Pretest Posttest Control Group Design. Penelitian ini dilaksanakan di SMK N 1 Magelang, yang beralamat di Jalan Cawang No. 2 Kota Magelang. Pelaksanaan penelitian dilakukan pada semester 1 (kelas X semester 1. Subjek penelitian ini yaitu kelas X MC dan kelas X MA dengan jumlah masing-masing kelas yaitu
31 siswa. Kelompok kontrol menggunakan kelas $\mathrm{X}$ MC dan kelompok treatment menggunakan kelas X MA.

Penelitian eksperimen ini menggunakan Pretest Posttest Control Group Design dengan dua kelompok yang dipilih secara sampling insidental, kemudian diberi pretest untuk mengetahui keadaan awal, adakah perbedaan antara kelompok treatment dan kelompok kontrol. Kelompok kontrol ini adalah kelompok yang hanya diberikan materi di dalam kelas, sedangkan kelompok treatment ini adalah kelompok yang diberikan tindakan lebih berupa materi di dalam kelas dan diberikan perlakuan penerapan perangkat pengecoran aluminium dengan praktik pengecoran aluminium. Prosedur penelitian ini dapat diperjelas dengan Gambar1.

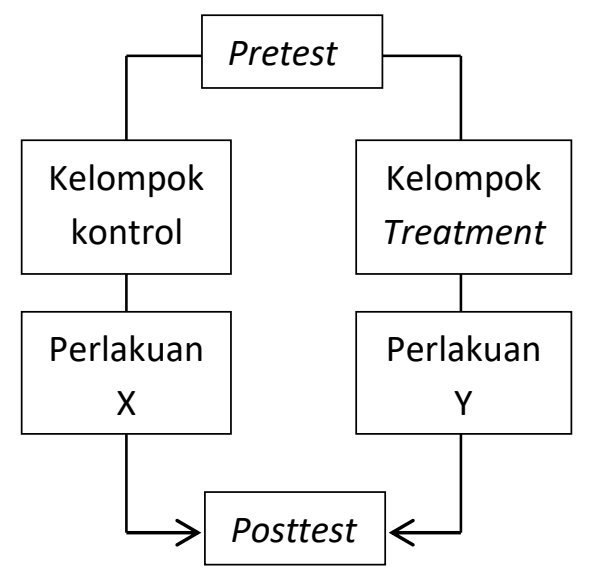

Gambar1. Prosedur penelitian

Keterangan:

$\mathrm{X}$ : perlakuan pembelajaran dengan teori di dalam kelas

Y : perlakuan pembelajaran dengan teori di dalam kelas dan penerapan perangkat praktik pengecoran aluminium

Pada proses pembelajaran dengan teori di dalam kelas materi yang disampaikan sama antara kelompok kontrol dengan kelompok treatment. Kemudian pada kelompok treatment ini ditambah dengan perlakuan penerapan peralatan pengecoran aluminium untuk praktik pengecoran dan pada akhir pembelajaran 
kedua kelompok diberikan posttest untuk mengetahui hasil belajar siswa.

Data yang diperoleh yaitu dari lembar instrumen berbentuk tes soal kemampuan materi pengecoran aluminium yang diberikan pada ujian pretest dan posttest. Data penelitian ini berbentuk nilai tes prestasi belajar siswa yang diambil dari nilai pretest dan nilai posttest kelompok kontrol maupun kelompok treatment.

Teknik analisis data yang digunakan yaitu analisis data statistik diskriptif dengan menghitung harga mean $(\mathrm{Me})$, median $(\mathrm{Md})$, dan modus (Mo). Pengujian hipotesis menggunakan Uji Tanda. Uji Tanda ini berguna untuk mengetahui perbedaan hasil belajar pada nilai pretest dengan posttest dari masing-masing kelompok sampel.

Pada pengujian hipotesis penelitian ini berbentuk hipotesis komparatif dua sampel independen. Adapun hipotesis nol (Ho) dan hipotesis alternatif $(\mathrm{Ha})$ pada penelitian adalah: Ho = tidak ada perbedaan prestasi hasil belajar siswa antara kelompok kontrol dengan kelompoktreatment.

$\mathrm{Ha}=$ ada perbedaan prestasi hasil belajar antara siswa kelompok kontrol dengan kelompoktreatment.

Kriteria Ho ditolak apabila Nilai Kritis $h$ hitung lebih kecil atau sama dengan Nilai Kritis $h$ tabel, sedangkan kriteria penerimaan Ha jika Nilai Kritis h hitung lebih kecil atau sama dengan Nilai Kritis h tabel.

\section{HASIL DAN PEMBAHASAN}

Subjek pada kelompok kontrol ini sebanyak 31 siswa. Dari hasil pretest, nilai tertinggi yang diperoleh siswa adalah 63,30 dan nilai terendah yang diperoleh siswa adalah 30,00 dengan nilai rata-rata (mean) yang diraih siswa pada pretest adalah 47,08 ; skor tengah (median) sebesar 46,60; dan modus sebesar 53,30. Distribusi skor hasil pretest kelompok kontrol dapat dilihat pada Tabel 1.
Tabel 1. Distribusi skor hasil pretest kelompok kontrol

\begin{tabular}{lcc}
\hline Interval & Frekuensi & Frekuensi Relatif $(\%)$ \\
\hline $30,00-35,55$ & 1 & 3.23 \\
$35,56-41,11$ & 9 & 29.03 \\
$41,12-46,67$ & 7 & 22.58 \\
$46,68-52,23$ & 2 & 6.45 \\
$52,24-57,79$ & 8 & 25.81 \\
$57,80-63,35$ & 4 & 12.90 \\
\hline Jumlah & 31 & 100.00 \\
\hline \multicolumn{4}{c}{ Hasil pretest menunjukkan bahwa siswa } \\
yang mencapai nilai kriteria ketuntasan \\
minimal belum ada dan siswa mempunyai \\
kemampuan di bawah rata-rata kriteria \\
ketuntasan minimum.
\end{tabular}

Kemudian dari hasil posttest, nilai tertinggi yang diperoleh siswa adalah 86,60 dan nilai terendah yang diperoleh siswa adalah 56,60 dengan nilai rata-rata (mean) yang diraih siswa pada post test adalah 72,43 ; skor tengah (median) sebesar 73,30; modus sebesar 70,00. Distribusi skor hasil posttest kelompok kontrol dapat dilihat pada Tabel 2.

Tabel 2. Distribusi skor hasil posttest kelompok kontrol

\begin{tabular}{ccc}
\hline Interval & Frekuensi & $\begin{array}{c}\text { FrekuensiRelatif } \\
(\%)\end{array}$ \\
\hline $56,6-61,6$ & 1 & 3.23 \\
$61,7-66,7$ & 7 & 22.58 \\
$66,8-71,8$ & 7 & 22.58 \\
$71,9-76,9$ & 10 & 32.26 \\
$77,0-82,0$ & 2 & 6.45 \\
$82,1-87,1$ & 4 & 12.90 \\
\hline Jumlah & 31 & 100.00 \\
\hline
\end{tabular}

Dari hasil posttest menunjukkan bahwa kebanyakan siswa masih dalam tahap pembelajaran yang belum maksimal terbukti dengan siswa yang lulus di atas nilai kriteria ketuntasan minimal 75 ada 10 orang dengan rentang nilai $75-77$ ada 4 siswa dan rentang nilai 77-87 sebanyak 6 siswa.

Subjek pada kelompok treatment sebanyak 31 siswa. Dari hasil pretest, nilai tertinggi yang diperoleh siswa adalah 60,00 dan nilai terendah yang diperoleh siswa adalah 33,30 dengan nilai rata-rata (mean) yang diraih siswa pada pretest adalah 46,21; skor tengah (median) sebesar 46,60; modus sebesar 36,60. 
Distribusi skor hasil pretest kelompok treatment dapat dilihat pada Tabel 3.

Tabel 3. Distribusi skor hasil pre test kelompok treatment

\begin{tabular}{ccc}
\hline Interval & Frekuensi & FrekuensiRelatif $(\%)$ \\
\hline $33,3-37,75$ & 6 & 19.35 \\
$37,76-42,21$ & 3 & 9.68 \\
$42,22-46,67$ & 8 & 25.81 \\
$46,68-51,13$ & 6 & 19.35 \\
$51,14-55,59$ & 5 & 16.13 \\
$55,60-60,05$ & 3 & 9.68 \\
\hline Jumlah & 31 & 100 \\
\hline
\end{tabular}

Hasil pretest menunjukkan bahwa siswa yang mencapai nilai kriteria ketuntasan minimal belum ada sama sekali dan siswa mempunyai kemampuan di bawah rata-rata kriteria ketuntasan minimum. Kemudian dari hasil posttest, nilai tertinggi yang diperoleh siswa adalah 90,00 dan nilai terendah yang diperoleh siswa adalah 60,00 . Nilai rata-rata (mean) yang diraih siswa pada post test adalah 82,78; skor tengah (median) sebesar 83,30; modus sebesar 83,30. Distribusi skor hasil posttest kelompok treatment dapat dilihat pada Tabel 4.

Tabel 4. Distribusi skor hasil posttest kelompok treatment

\begin{tabular}{ccc}
\hline Interval & Frekuensi & FrekuensiRelatif(\%) \\
\hline $60,0-65,0$ & 1 & 3.23 \\
$65,1-70,1$ & 0 & 0.00 \\
$70,2-75,2$ & 0 & 0.00 \\
$75,3-80,3$ & 9 & 29.03 \\
$80,4-85,4$ & 9 & 29.03 \\
$85,5-90,5$ & 12 & 38.71 \\
\hline Jumlah & 31 & 100.00 \\
\hline
\end{tabular}

Hasil posttest menunjukkan bahwa siswa yang belum mencapai nilai ketuntasan minimal hanya satu siswa dan 30 siswa mendapatkan nilai di atas ketuntasan minimal, di mana siswa yang lulus dari kriteria ketuntasan minimal nilai terendahnya yaitu 75,3 dan nilai tertinggi 90,5. Dengan demikian, siswa kelompok kontrol yang memenuhi kriteria ketuntasan minimal sebanyak 10 siswa dengan nilai ketuntasan minimal 75. Selain itu terdapat perbedaan peningkatan prestasi belajar perseorangan di mana prestasi belajar siswa yang terendah yaitu $3 \%$ dan tertinggi yaitu 43\%. Perbedaan peningkatan prestasi siswa yang terendah dan tertinggi dapat ditampilkan pada Gambar 2.

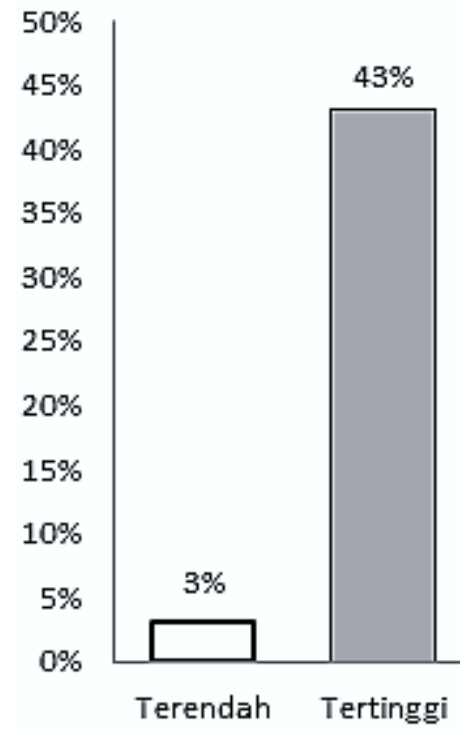

Gambar 2. Grafik perbedaan peningkatan prestasi belajar siswa kelompok kontrol

Perbedaan peningkatan prestasi belajar tersebut terjadi karena siswa yang persentase peningkatan hasil belajarnya rendah mengantuk saat diberikan penjelasan materi di dalam kelas dan cenderung bosan untuk mencatat materi yang disampaikan. Sedangkan siswa yang persentase peningkatan hasil belajarnya tinggi memperhatikan dan mencatat setiap pokok-pokok materi yang disampaikan di dalam kelas.

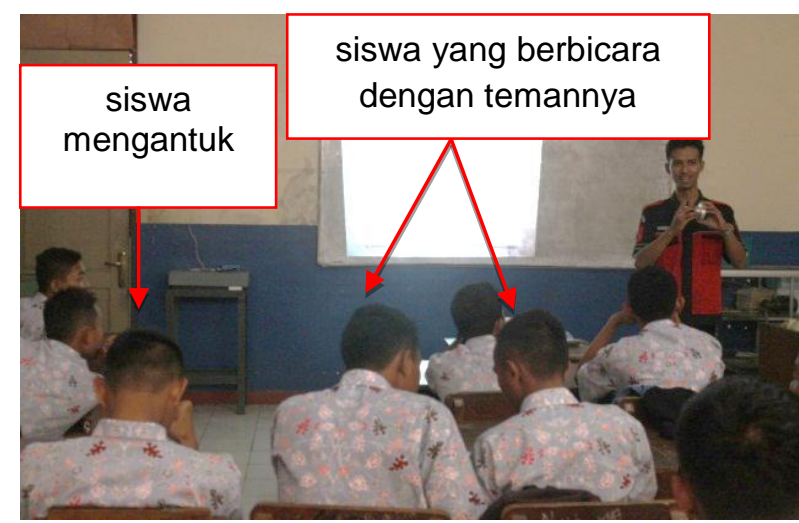

Gambar 3.Siswa yang mengantuk dan berbicara dengan temannya 
Jika dikaitkan dengan faktor-faktor yang mempengaruhi prestasi belajar, keadaan tersebut termasuk dalam faktor intern yaitu faktor psikologis siswa. Faktor psikologis yang mencakup intelegensi, perhatian, minat, bakat, motivasi, serta kesiapan belajar siswa ini kurang. Selain itu, faktor kelelahan siswa juga menjadikan prestasi belajar siswa menurun, apabila siswa sudah merasa lelah mereka cenderung malas untuk mendengarkan dan mencatat materi yang disampaikan guru. Sehingga saat diberikan penilaian posttest siswa yang persentase peningkatan belajarnya rendah ini kesulitan dalam menjawab soal.

Kemudian pada siswa kelompok treatment yang memenuhi kriteria ketuntasan minimal sebanyak 30 siswa dengan nilai ketuntasan minimal 75. Selain itu, terdapat perbedaan peningkatan prestasi belajar perseorangan di mana prestasi belajar yang terendah yaitu $23 \%$ dan tertinggi yaitu $53 \%$. Perbedaan peningkatan prestasi siswa yang terendah dan tertinggi dapat ditampilkan pada Gambar 4.

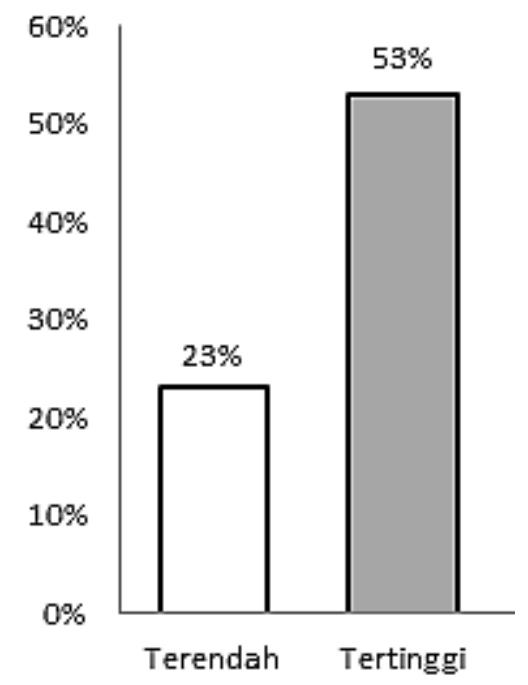

Gambar 4.Grafik perbedaan peningkatan prestasi belajar siswa kelompok treatment

Perbedaan persentase peningkatan hasil belajar siswa ini terjadi karena hanya satu siswa saja yang tidak lulus kriteria ketuntasan minimal. Perbedaan prestasi belajar siswa yang tidak terlalu signifikan ini dipengaruhi oleh penggunaan perangkat praktik pengecoran aluminium sebagai media pembelajaran untuk memperjelas penyampaian pesan agar tidak terlalu verbalistis kepada siswa. Sehingga materi yang disampaikan oleh guru lebih mudah untuk dipahami oleh siswa dengan cara mempraktikkan secara langsung.

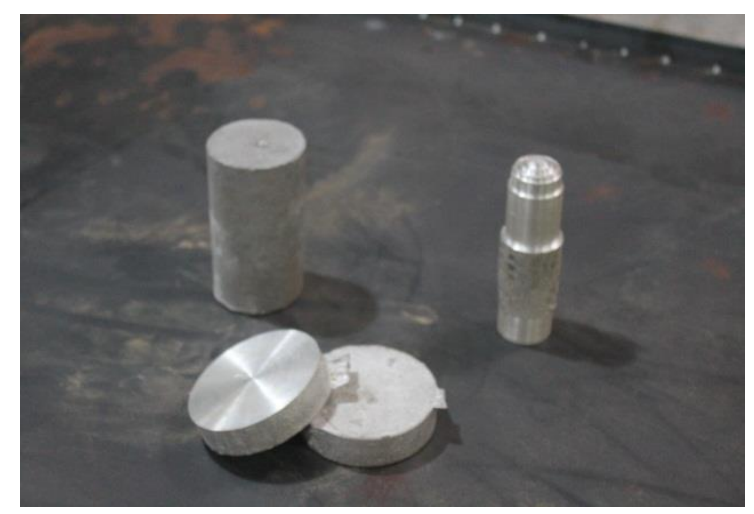

Gambar 5. Hasil praktik pengecoran siswa

Selain itu siswa yang persentase peningkatan hasil belajarnya rendah ini terjadi karena saat materi pengantar dan praktik pengecoran aluminium mahasiswa tersebut bermain sendiri dengan peralatan di dalam bengkel.

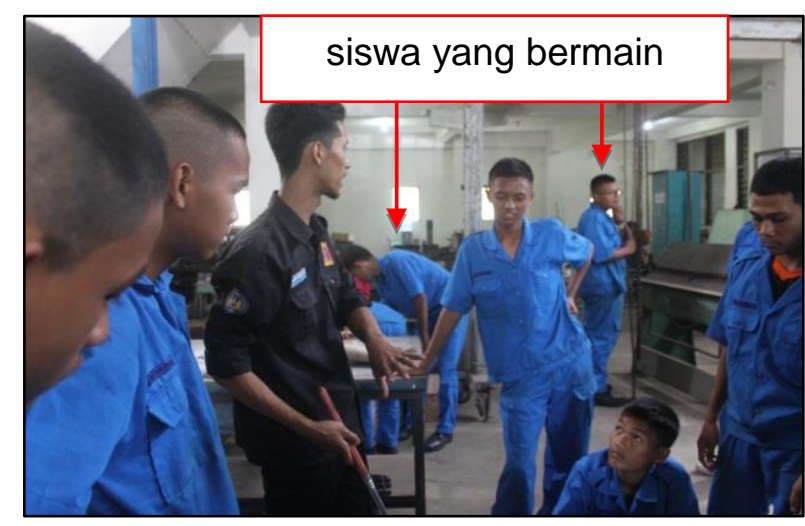

Gambar 6. Siswa yang bermain dengan peralatan bengkel

Apabila dikaitkan dengan faktor-faktor yang mempengaruhi prestasi belajar siswa, maka kondisi tersebut termasuk pengaruh faktor eksternal dari siswa. Faktor eksternal yaitu kondisi lingkungan di sekolah khususnya bengkel kurang mendukung untuk proses belajar. Hal ini terjadi karena Jurusan Permesinan SMK N 1 Magelang belum mempunyai bengkel khusus untuk praktik pengecoran, jadi saat praktik pengecoran masih 
menggunakan bengkel las yang banyak peralatan.

Hasil penelitian menunjukkan adanya perbedaan prestasi belajar antara kelompok kontrol dengan kelompok perlakuan. Perbedaan ini terjadi karena kelompok kontrol hanya diberikan materi pengecoran aluminium di dalam kelas, Sedangkan kelompok perlakuan diberikan materi pengecoran aluminium dan praktik menggunakan perangkat praktik pengecoran aluminium. Siswa pada kelompok kontrol saat diberikan materi di dalam kelas ada yang merasa bosan bahkan mengantuk, beberapa siswa ada yang mencatat materi sedangkan yang lainya berbicara dengan teman satu meja. Sedangkan siswa pada kelompok perlakuan yang diberikan materi pengecoran aluminium dan praktik menggunakan perangkat praktik pengecoran aluminium merasa tertarik dan antusias memperhatikan penjelasan dari peneliti.

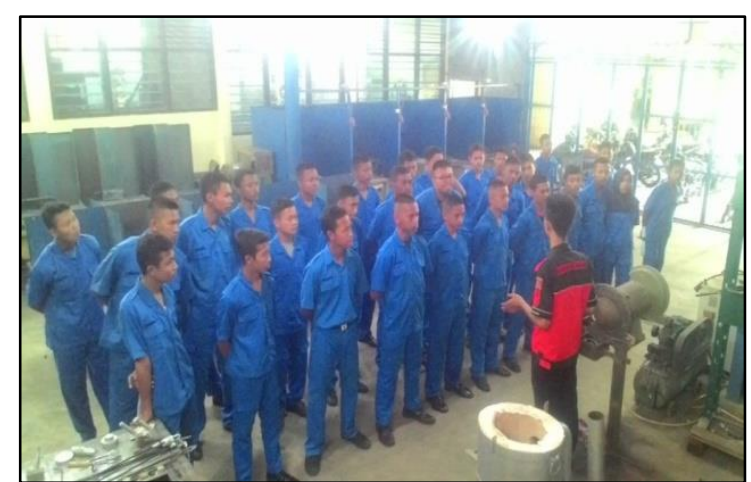

Gambar 7. Antusias siswa dalam memperhatikan penjelasan praktik pengecoran

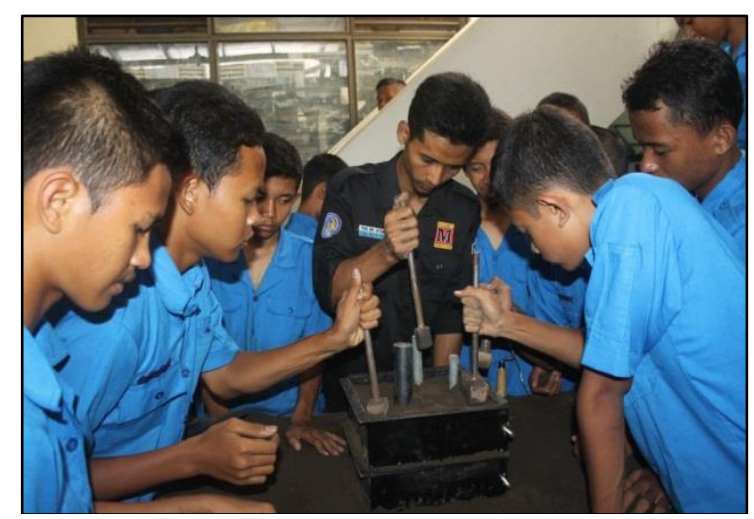

Gambar 8. Antusias siswa dalam praktik membuat cetakan pasir

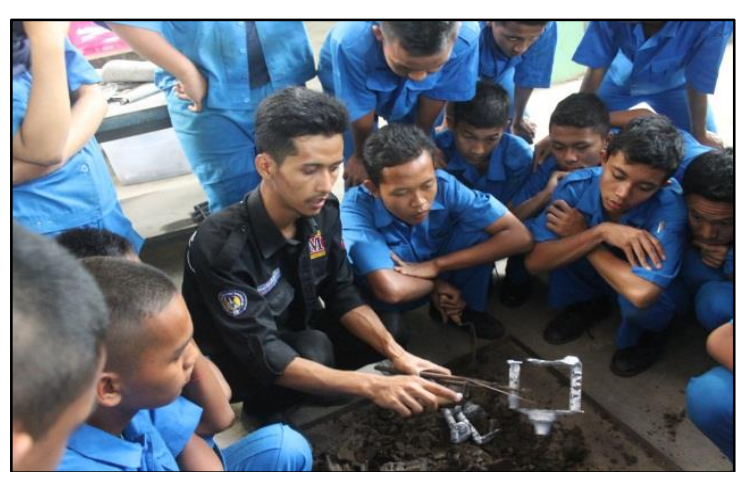

Gambar 9. Antusias siswa dalam memperhatikan cacat hasil pengecoran

Perbandingan persentase rata-rata peningkatan hasil belajar kelompok kontrol dengan kelompok perlakuan tersebut disampaikan dalam Gambar 10.

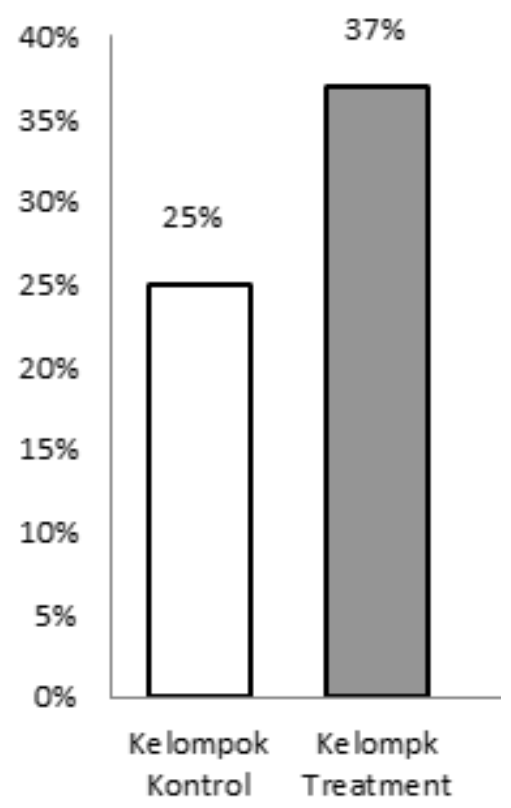

Gambar 10. Grafik persentase peningkatan hasil belajar siswa

Berdasarkan Gambar 10 diketahui bahwa kelompok kontrol meningkat hanya $25 \%$, sedangkan pada kelompok perlakuan yang diberikan materi pengecoran aluminium dan praktik menggunakan perangkat praktik pengecoran aluminium pada mata pelajaran teknologi mekanik sebesar $37 \%$. Kontribusi perangkat praktik pengecoran aluminium terhadap prestasi belajar siswa ini tidak terlalu tinggi. Hal ini terjadi karena beberapa faktor 
yaitu keterbatasan waktu untuk menyampaikan materi di dalam kelas dan keterbatasan ruang saat praktik pengecoran aluminium, kurangnya pengawasan terhadap siswa yang asyik bermain saat melaksanakan praktik pengecoran, dan pengaruh variabel-variabel lain yang tidak bisa dikontrol oleh peneliti.

Walaupun demikian, hasil penelitian ini sudah menunjukkan perbedaan yang signifikan dan persentase pengaruh perangkat praktik pengecoran ini sebesar $12 \%$, dihitung dari pengurangan rata-rata persentase peningkatan hasil belajar kelompok tretament dengan kelompok control (37\% - 25\%).

\section{SIMPULAN}

Hasil penelitian menunjukkan bahwa: (1) Prestasi belajar siswa kelompok kontrol setelah diberikan tindakan yang memenuhi kriteria ketuntasan minimal sebanyak 10 siswa dari 31 siswa, sedangkan prestasi belajar kelompok treatment setelah diberikan tindakan yang memenuhi kriteria ketuntasan minimal sebanyak 30 siswa dari 31 siswa dengan nilai kriteria ketuntasan minimal 75. (2) Rata-rata prestasi belajar kelompok treatment lebih baik daripada kelompok kontrol yang tidak menerapkan perangkat praktik pengecoran aluminium, yaitu rata-rata prestasi belajar kelompok treatment sebesar 82,78> kelompok kontrol sebesar 72,43. Peningkatan rata-rata prestasi belajar kelompok treatment $37 \%$ sedangkan kelompok kontrol hanya 25\%, sehingga rata-rata prestasi belajar kelompok treatment lebih tinggi 12\% daripada kelompok kontrol. (3) Terdapat perbedaan prestasi belajar siswa kelompok treatment yang menerapkan perangkat praktik pengecoran aluminium dan kelompok kontrol yang hanya diberikan teori pengecoran aluminium di ruang kelas. Dengan demikian, penerapan perangkat praktik pengecoran aluminium pada mata pelajaran teknologi mekanik di SMK N 1 Magelang memberikan dampak positif terhadap prestasi hasil belajar siswa kelas $\mathrm{X}$ jurusan pemesinan. Berangkat dari hal tersebut, sebaiknya praktik pengecoran aluminium menjadi kegiatan yang wajib ditempuh siswa untuk menunjang prestasi belajar, khususnya pengerjaan logam. Selain itu, sebelum praktik pengecoran guru memberikan demo proses pengecoran aluminium serta menjelaskan perangkat praktik yang digunakan beserta fungsinya untuk memberikan pemahaman lebih kepada siswa. Ke depan diharapkan ada penelitian tentang pengembangan tungku krusibel sehingga tidak hanya logam aluminium yang digunakan untuk praktik pengecoran.

\section{DAFTAR RUJUKAN}

Baroto, R. (t.thn.). academia.edu. Dipetik 12 06, 2016, dari academia.edu: http://www.academia.edu/9042487/SK _DIRJEN_MENDIKBUD__SPEKTRUM_PENDIDIKAN_SMK

Depdiknas. (t.thn.). pendis.kemenag.go.id. Dipetik 12 06, 2016, dari pendis.kemenag.go.id:

http://pendis.kemenag.go.id/file/doku men/uuno20th2003ttgsisdiknas.pdf

Fitrianto. (2016). Implementasi Tungku Pelebur Logam Untuk Meningkatkan Hasil Belajar Materi Pengecoran Logam Siswa Kelas X Jurusan Teknik Pemesinan di SMK Muhamadiyah Prambanan . Yogyakarta: UNY.

Slameto. (2003). Belajar dan Faktor-faktor yang Mempengaruhinya. Jakarta: Rineka Cipta. 